\title{
Recent advances in understanding the Th1/Th2 effector choice
}

\author{
Matthew J. Butcher 1* Jinfang Zhu (iD ${ }^{1 *}$ \\ ${ }^{1}$ Molecular and Cellular Immunoregulation Section, Laboratory of Immune System Biology, National Institute of Allergy and Infectious Diseases, National \\ Institutes of Health, Bethesda, MD, USA
}

\begin{abstract}
For over 35 years since Mosmann and Coffman proposed the seminal "type 1 T helper (Th1)/type 2 T helper (Th2)" hypothesis in 1986, the immunological community has appreciated that naïve CD4 T cells need to make important decisions upon their activation, namely to differentiate towards a Th1, Th2, Th17 (interleukin-17-producing T helper), follicular T helper (Tfh), or regulatory $\mathrm{T}$ cell (Treg) fate to orchestrate a variety of adaptive immune responses. The major molecular underpinnings of the Th1/Th2 effector fate choice had been initially characterized using excellent reductionist in vitro culture systems, through which the transcription factors T-bet and GATA3 were identified as the master regulators for the differentiation of Th1 and Th2 cells, respectively. However, Th1/Th2 cell differentiation and their cellular heterogeneity are usually determined by a combinatorial expression of multiple transcription factors, particularly in vivo, where dendritic cell (DC) and innate lymphoid cell (ILC) subsets can also influence $T$ helper lineage choices. In addition, inflammatory cytokines that are capable of inducing Th17 cell differentiation are also found to be induced during typical Th1- or Th2-related immune responses, resulting in an alternative differentiation pathway, transiting from a Th17 cell phenotype towards Th1 or Th2 cells. In this review, we will discuss the recent advances in the field, focusing on some new players in the transcriptional network, contributions of DCs and ILCs, and alternative differentiation pathways towards understanding the Th1/Th2 effector choice in vivo.
\end{abstract}

\section{Keywords}

Th1/Th2 effector choice, dendritic cells, innate lymphoid cells

\section{Peer Review}

The peer reviewers who approve this article are:

1. Kenneth J Oestreich, Department of Microbial Infection and Immunity, The Ohio State University College of Medicine and Wexner Medical Center, Columbus, OH, USA

Competing interests: No competing interests were disclosed.

2. Dorina Avram, Department of Immunology, Moffitt Cancer Center, Tampa, FL, USA

Namrata Gautam, Department of Immunology, Moffitt Cancer Center, Tampa, FL, USA

Competing interests: No competing interests were disclosed. 
*Corresponding author: Matthew J. Butcher (matthew.butcher@niaid.nih.gov); Jinfang Zhu (jfzhu@niaid.nih.gov)

Competing interests: The authors declare that they have no competing interests.

Grant information: This work is supported by the Division of Intramural Research of NIAID (US National Institutes of Health).

Copyright: (C) 2021 Zhu J et al. This is an open access article distributed under the terms of the Creative Commons Attribution License, which permits unrestricted use, distribution, and reproduction in any medium, provided the original work is properly cited.

How to cite this article: Butcher MJ and Zhu J. Recent advances in understanding the Th1/Th2 effector choice. Faculty Reviews 2021 10:(30) https://doi.org/10.12703/r/10-30

Published: 15 Mar 2021, Faculty Reviews 10:(30) https://doi.org/10.12703/r/10-30 


\section{Introduction}

The ability of naïve CD4 $\mathrm{T}$ cells to differentiate into distinct cytokine-producing effector $\mathrm{T}$ helper (Th) cell subsets has been well appreciated over the last 35 years. The initial hypothesis set forth by Mosmann and Coffman in 1986 that at least two subsets of CD4 Th cell clonotypes could be distinguished based on the production of interferon (IFN) $\gamma$ or IL- $4^{1}$ has since been expanded to encompass new Th subsets, including type 1 IFN $\gamma$-producing Th (Th1) cells, type 2 IL-4/IL-5/IL-13-secreting Th (Th2) cells, IL-17A/IL-17F/IL-22-secreting Th (Th17) cells, $\mathrm{T}$ follicular helper ( $\mathrm{Tfh}$ ) cells, and regulatory $\mathrm{T}$ cell (Treg) populations ${ }^{2}$. Indeed, the initial hypothesis set forth sparked a period of discovery in which the major molecular and cellular events leading up to the differentiation of naïve CD4 T cells towards Th1 and Th2 effector cells were characterized using excellent reductionist in vitro models.

Th1 cells are key players in helping to mount a host defense against intracellular pathogens, including protozoa, bacteria, and viruses, but are also involved in the development of certain types of autoimmune diseases ${ }^{3-5}$. Lineage-specific master transcription factors often play decisive roles in determining cell fate. Following Mosmann and Coffman's hypothesis, T-bet was identified $^{6-8}$ as the Th1-lineage master transcription factor, as T-bet directly regulates the production of IFN $\gamma$. Soon after, several distinct upstream regulatory pathways were described to promote Th1 cell differentiation. As T-bet can positively regulate IFN $\gamma$ production, autocrine IFN $\gamma-$ IFN $\gamma \mathrm{R}-$ Stat 1 signaling can reinforce T-bet expression to solidify the Th1 phenotype ${ }^{9,10}$. IL-12 can also potently induce T-bet expression and Th1 polarization independent of IFN $\gamma$ signaling ${ }^{11,12}$. Additionally, at the onset of an infection, IL-27 can induce IL-12R on naïve CD4 $\mathrm{T}$ cells, making them more susceptible to IL-12-mediated T-bet expression and Th1 polarization ${ }^{13}$. Lastly, T-bet was reported to induce its own expression ${ }^{14}$. However, T-bet autoregulation may not be required in the presence of either IL-12 or IFN $\gamma$. Nevertheless, T-bet and IL-12-induced pStat4 may synergize to remodel the Ifng locus and optimally induce IFN $\gamma$ production $^{12}$.

In contrast to Th1 cells, Th2 cells are primarily important in helping to mount a defense against helminth infections and exposure to venoms, but they also participate in different types of allergic diseases including asthma, atopic dermatitis, allergic rhinitis, and food allergy ${ }^{15-19}$. Ten years after the Th1/Th2 hypothesis, GATA3 was identified as the master transcription factor responsible for Th2 cell differentiation ${ }^{20-23}$. However, unlike T-bet, which is induced during Th1 cell differentiation, GATA3 is already expressed by naïve CD4 T cells at low levels and is required for $\mathrm{CD} 4 \mathrm{~T}$ cell development in the thymus ${ }^{24,25}$. Upon encountering antigen presentation and IL-4, activation of Stat6 is sufficient to induce GATA3 upregulation and Th2 polarization. However, GATA3 is also sensitive to the strength of T cell receptor (TCR) stimulation, as low-dose/weaker TCR stimulation is sufficient to upregulate GATA3 expression in the absence of IL-4/Stat6 signaling ${ }^{26}$, consistent with the notion that TCR signaling strength could affect the fate of $\mathrm{T}$ cell differentiation $^{27-29}$. Thus, there are IL-4-dependent and IL-4independent mechanisms of GATA3 induction and Th2 cell differentiation, particularly in vivo, and GATA3 is critical for Th2 cell differentiation both in vitro and in vivo ${ }^{22}$. GATA3 directly binds to the Il4/Ill3 gene locus. While GATA3 can induce $I l 5$ and $I l 13$ transcription through binding to their promoters ${ }^{30,31}$, GATA3 mainly affects Il4 expression through regulating epigenetic modifications at the Th2 cytokine gene locus ${ }^{25}$.

Following the identification of T-bet and GATA3 as Th1- and Th2-polarizing transcription factors, respectively, it became readily apparent that lineage cross-regulation occurs in order to solidify one $\mathrm{T}$ effector fate over the other. For example, T-bet was shown to suppress GATA3 transcription ${ }^{12,32}$ and inhibit GATA3 function through direct protein-protein interaction ${ }^{33}$. In addition, T-bet and GATA3 both colocalize at key Th1- and Th2-related genes, and endogenous T-bet is sufficient to inhibit GATA3 function during Th1 polarization, thereby enforcing a Th1 program ${ }^{12,34,35}$. In contrast, during Th2 polarization, GATA3 may suppress Stat4 expression, suppress Runx3-mediated IFN $\gamma$ production, and epigenetically silence the $T b \times 21$ locus to ensure Th2 polarization ${ }^{25,36,37}$.

In this review, we will discuss some recent interesting advances towards understanding the Th1/Th2 effector cell "choice", particularly during in vivo immune responses, which include the role of new players in the transcriptional network, the contributions of dendritic cells (DCs) and innate lymphoid cells (ILCs) in the initiation of $\mathrm{T}$ cell differentiation, and the alternative differentiation pathways transiting from Th17 cells to Th1 or Th2 cells. While some of the topics that will be discussed are also relevant to Th17-, Treg-, and Tfh-mediated cellular responses as well as their plasticity, these subsets will not be discussed in detail, and we refer the reader to several excellent reviews ${ }^{2,38-45}$.

\section{New roles for known transcription factors in regulating the differentiation and functions of Th1 and Th2 cells}

Despite all that we have learned about the Th1/Th2 dichotomy in the past 35 years, there is still much to learn about the Th1/Th2 choice in the context of transcriptional networks. Specifically, non-lineage-specifying transcription factor networks can influence the quality of a Th1 or Th2 response by influencing their cytokine repertoire. Interestingly, several recent studies have highlighted non-lineage-restricted transcription factors, Bhlhe40 and B cell lymphoma 11B (Bcl11b), in affecting the cytokine repertoires of Th1 and Th2 cells.

Three reports have recently shown Bhlhe40 to be a key non-lineage-related cytokine modulator, demonstrating a role for Bhlhe40 in Th1 immunity in Toxoplasma gondii and Mycobacterium tuberculosis infection models and in Th2 immunity in a model of Heligmosomoides polygyrus infection ${ }^{4-48}$. Two groups independently demonstrated that Bhlhe40 plays a key role in suppressing IL-10 production by Th1 cells, functioning as a key inflammation/anti-inflammation switch. Yu and 
colleagues $^{46}$ demonstrated that a CD4 $\mathrm{T}$ cell-restricted knockout of Bhlhe 40 resulted in increased IL-10 production and decreased IFN $\gamma$ production by $\mathrm{T}$ cells in a $T$. gondii infection model. Bhlhe40 may suppress IL-10 production via suppression of c-Maf and/or Aiolos but promotes IFN $\gamma$ production in a T-bet-independent manner. Similarly, Huynh and colleagues ${ }^{47}$ demonstrated that Bhlhe40 is an essential repressor of IL-10 during $M$. tuberculosis infection. In the context of $H$. polygyrus helminth infection, Jarjour and colleagues ${ }^{48}$ found that Th2 cells require Bhlhe40 in order to mount an effective anti-helminth immune response. Interestingly, in their model, Bhlhe40 controlled the production of granulocyte-macrophage colony-stimulating factor (GM-CSF) and IL-5 cytokines within gut Th2 cells, and both cytokines are required for efficient eosinophil recruitment and helminth control, suggesting that Bhlhe40 plays a key role in controlling the production of GM-CSF, IL-10, and other cytokines in multiple T cell subsets, including Th1, Th17, and Th2 cells. All together, these data suggest that Bhlhe40 plays an important lineage-independent cytokine-modifying role in Th1, Th2, and Th17 cells by promoting inflammation via inducing GM-CSF and suppressing IL-10.

There have also been several recent reports that have highlighted a non-lineage modulatory role for Bcl11b on Th1 and Th2 responses. Bcl11b is a critical transcription factor for early $\mathrm{T}$ cell development and is expressed by all $\mathrm{T}$ cells starting from the $\mathrm{CD} 4 / \mathrm{CD} 8$ double negative $(\mathrm{DN})$ stage $2^{49}$. Bcl11b is critically required for $\mathrm{V} \beta$-DJ $\beta$ recombination and Tcrb expression at the DN3 to DN4 transition, as well as positive selection at the $\mathrm{CD}^{+}{ }^{+} \mathrm{CD}^{+}{ }^{+} \mathrm{DP}$ stage ${ }^{50,51}$. In addition, Bcl11b plays an important role in regulating the development and functions of mature $\mathrm{T}$ cell subsets ${ }^{52}$. Furthermore, Bcl11b suppresses the cell fate of natural killer cells and is important for the development of ILC2 $\mathrm{s}^{53-57}$. Recently, Fang and colleagues ${ }^{58}$ have demonstrated a novel role for Bcl11b in suppressing Th1 cell differentiation while simultaneously limiting the expression of Th2 cell-associated genes. In this study, it has been shown that Bcl11b physically interacts with GATA3 through protein-protein interaction and binds to common cis-regulatory elements of lineage-related genes that GATA3 binds in Th2 cells and thus limits IL-4, IL-5, and IL-13 production both in vitro and in vivo. Interestingly, GATA3 and Bcl11b also simultaneously suppressed Th1-associated genes by modulating H3K27ac and DNase I hypersensitivity sites within these gene loci. Strikingly, while Bcl11b limits Th2 cell responses at a later stage, it plays an important role in the initiation of Th2 responses ${ }^{59}$. Deletion of Bcl11b in naïve CD4 $\mathrm{T}$ cells results in a reduced $\mathrm{Th} 2$ response during helminth infection and in allergic asthma models, presumably because of a dysregulated balance between GATA3 and Runx3 expression in the absence of $\mathrm{Bcl11b}$. Interestingly, Bcl11b may also play a role in restricting the expression of Th2 lineage genes within Th17 cells, as Bcl11b-deficient Th17 cells were shown to express GATA3, IL-4, $\alpha 4 \beta 7$, and CCR9 in an experimental autoimmune encephalomyelitis (EAE) model ${ }^{60}$. Therefore, Bcll1b is not only critical for $\mathrm{T}$ cell development in the thymus but also important for
$\mathrm{T}$ cell differentiation in the periphery, and its functions are highly cell type (or developmental stage) specific.

Interestingly, the aforementioned effects of Bhlhe 40 and Bcl11b on the activation and differentiation of Th2 cells were recently confirmed by Henriksson and colleagues ${ }^{61}$. Expanding on the previous work focused on the network of transcription factors involved with Th17 cell activation versus differentiation ${ }^{62}$, Henriksson and colleagues utilized a combination of genomewide CRISPR knockout libraries combined with RNAseq, ATAC-Seq, and ChIP-seq to dissect out the regulatory circuitry controlling the activation versus differentiation of Th2 cells in vitro. As a result of their efforts, they not only confirmed GATA3, Stat6, Batf, PPAR $\gamma$, and IRF4 as key transcription factors that are involved in Th2 cell differentiation and activation but also revealed Bhlhe40, Bcl11b, and Xbp1 as transcription factors that are involved in Th2 cell activation. While more factors that are involved in regulating Th1/Th2 differentiation and functions are still being discovered, including the p53 family protein p73, which affects Th1 cell differentiation ${ }^{63}$, and Blimp-1, which regulates GATA3 expression and thus Th2 cell differentiation ${ }^{64}$, the combination of novel genome-level technologies such as CRISPR knockout with high-throughput sequencing will hopefully reveal more non-lineage-related transcription factors in modulating CD4 T cell differentiation.

\section{DC subsets in making the Th1/Th2 decision}

In order for naïve $\mathrm{T}$ cells to differentiate towards $\mathrm{Th} 1$ or $\mathrm{Th} 2$ effector cell fates in vivo, TCR stimulation via antigen presentation, co-stimulation, and polarizing cytokine cues, such as IL-12, IL-27, etc., are required. DCs are the premier antigen-presentation cell population in vivo, and they are ultimately required to activate and expand antigen-specific CD4 $\mathrm{T}$ cells via peptide-MHCII-TCR interactions (Figure 1). As such, DCs and DC subsets have garnered attention in the literature based on their differences in antigen presentation and $\mathrm{T}$ cell polarization capabilities. While the topic of $\mathrm{DC}$ subsets has been expertly reviewed elsewhere ${ }^{43,65,66}$, briefly, there are several subsets of DCs: conventional type 1 DCs (cDC1s), conventional type 2 DCs (cDC2s), plasmacytoid DCs (pDCs), monocyte-derived DCs (moDCs), and Langerhans cells (LCs), which differ based on their anatomical locations, ontogeny, and antigen-presentation capacities. Interestingly, out of the aforementioned subsets, conventional DCs are the most abundant and have been demonstrated to differ in terms of their abilities to induce Th1 or Th2 responses.

To efficiently polarize a naïve $\mathrm{T}$ cell to a Th1 phenotype, proTh1 polarizing cytokines are required, such as IL-12 and IL-27. Interestingly, $\mathrm{cDC} 1 \mathrm{~s}$ are a major source of $\mathrm{IL}-12$ in vivo ${ }^{67-69}$ and have been reported to be superior in terms of their ability to generate Th1 cells in ex vivo coculture systems ${ }^{70}$ when they are compared to cDC2s. cDC1s constitutively express $I l 12 b$ transcript and produce IL-12p40 protein in vivo ${ }^{71,72}$. Additionally, in experimental models of Th1 inflammation in the absence of cDC1s, the Th1 response is significantly compromised ${ }^{69,73-77}$, 


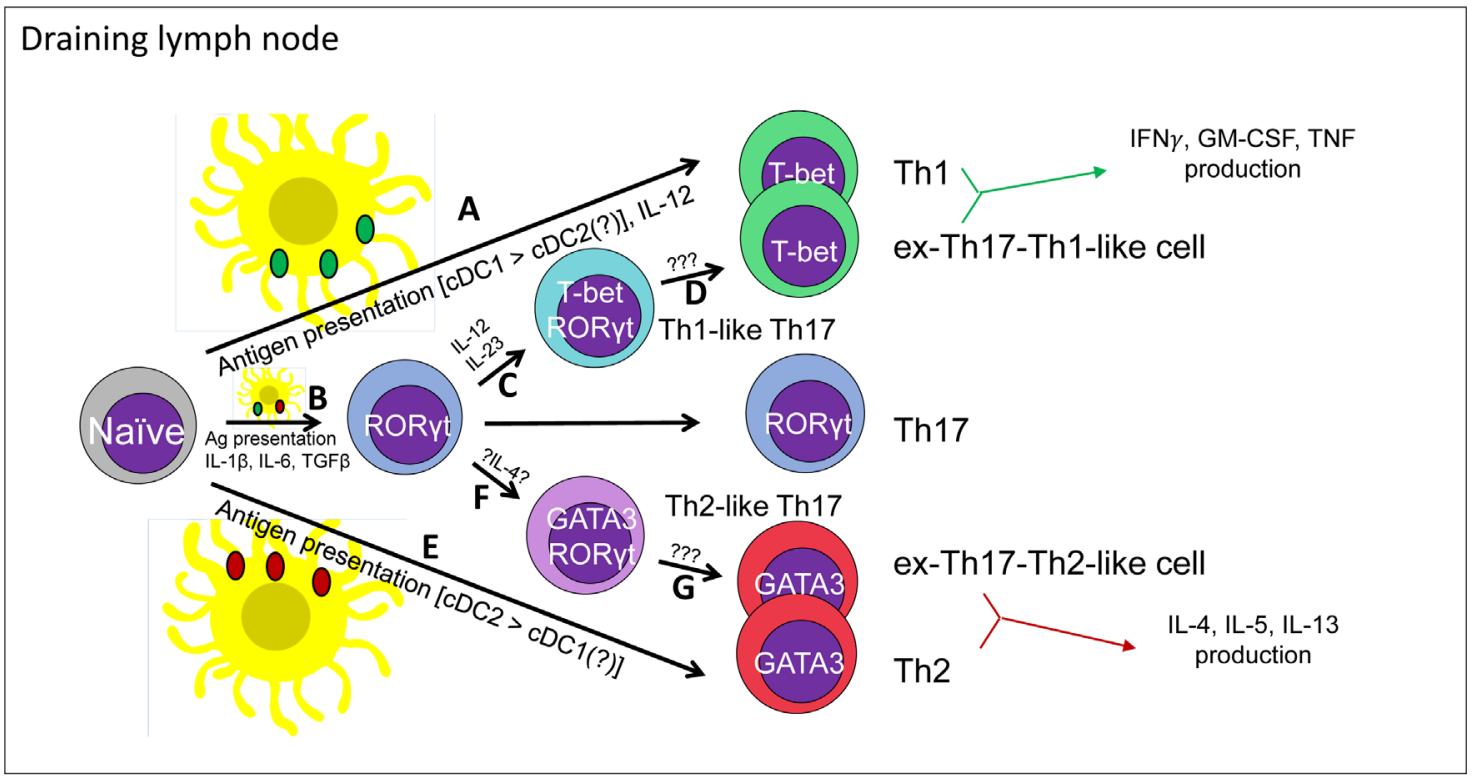

Figure 1. Contributions of dendritic cell subsets in the initiation of classical and alternative differentiation pathways for the generation of Th1 and Th2 cells in vivo. Presented here is our updated view of the Th1/Th2 T effector decision in vivo. In response to an in situ immunological insult, local antigen-presenting dendritic cells acquire Ag and home to the nearest draining lymph node to present Ags. In the case of a pro-Th1 insult, such as a bacterial infection, bacterial Ag-laden dendritic cells can present bacterial Ags to naïve T cells and produce IL-12 in order to help generate bacterial Ag-specific Th1 cells (A). In parallel, some bacterial PAMPs can trigger Ag-laden dendritic cells to produce pro-Th17 cytokines, including IL-1 $\beta$, IL-6, and TGF $\beta$ (B). Bacterial Ag-specific Th17 cells can subsequently respond to IL-12 and/or IL-23 in order to generate T-bet ${ }^{+}$Th1-like Th17 cells (C) and ex-Th17-Th1-like cells (D) via unclear mechanisms. In contrast to a pro-Th1 insult, allergen exposure or a helminth infection is able to elicit a Th2 Ag-specific T cell response. In this scenario, helminth- or allergen-Ag-bearing dendritic cells home to the nearest draining lymph node, where they may select for Ag-specific naïve T cells to generate an Ag-specific Th2 cell response (E). In parallel, some helminth- or allergen-Ag-laden dendritic cells may instead help to generate Th17 cells, which may subsequently give rise to GATA3 ${ }^{+}$Th2-like Th17 cells $(\mathbf{F})$ and ex-Th17-Th2-like cells $(\mathbf{G})$. Ag, antigen; cDC, conventional dendritic cell; GM-CSF, granulocyte-macrophage colony-stimulating factor; IFN, interferon; IL, interleukin; PAMP, pathogen-associated molecular pattern; TGF $\beta$, transforming growth factor beta; Th1, type $1 \mathrm{~T}$ helper; Th2, type $2 \mathrm{~T}$ helper; Th17, interleukin-17-producing T helper; TNF, tumor necrosis factor.

suggesting that cDC1s play a major role in generating Th1 responses in vivo. However, the following question arises: why are cDC1s able to produce basal levels of IL-12? The constitutive production of IL-12p40 doesn't seem to depend on commensals or the specific acquisition of antigen, as cDC1 IL-12p40 production is maintained in germ-free, naïve mice, suggesting that IL-12 production is either an intrinsic property of the $\mathrm{cDC} 1$ lineage or maintained by the microenvironment ${ }^{78}$. Homeostatic cDC1-derived IL-12 might function to support the generation of innate-like T-bet ${ }^{\text {high }} \mathrm{CD} 4$ memory phenotype cells. Interestingly cDC1s aren't the only DC subset that is able to initiate a Th1 response. There is some evidence to suggest that moDCs are also capable of driving Th1 responses during T. gondii and Salmonella infections as well as in immunizations with $\mathrm{CpG}$ or CFA-based adjuvants ${ }^{79-82}$, possibly in coordination with $\mathrm{cDC} 1 \mathrm{~s}$. Furthermore, during inflammation, cDC2s may acquire a hybrid inflammatory cDC2 phenotype in a manner that is reminiscent of $\mathrm{cDC} 1 \mathrm{~s}$ and moDCs, and type 1 IFN drives the generation of inflammatory cDC2s, which are capable of priming naive CD4 $\mathrm{T}$ cells to become IFN $\gamma$-producing
Th1 cells ${ }^{83}$. Another recent study has also demonstrated that TNFR $2 ~^{+}$cDC2 cells are able to drive Th1 responses following an intranasal immunization with cyclic dinucleotide as an adjuvant ${ }^{84}$, suggesting that both the cDC subsets and the adjuvant/PAMPs involved are important in determining the $\mathrm{T}$ cell differentiation outcome. Lastly, as one might expect, TLR3 and TLR9 agonists enhance DC IL-12p40 production and thus Th1 cell differentiation.

In contrast to the role of $\mathrm{cDC} 1 \mathrm{~s}$ in generating and recruiting Th1 cells, cDC2s, including IRF4 ${ }^{+}$cDC2s (some of which also express the transcription factor Klf4) in the skin, lungs, and intestinal lamina propria, are necessary for triggering $\mathrm{Th} 2$ responses in models of helminth infection or allergic diseases ${ }^{76,85-88}$. The exposure of $\mathrm{cDC} 2 \mathrm{~s}$ to helminth products, like Schistosoma mansoni egg antigen (SEA)-derived protein Omega1, can endow cDC2s with the capacity to induce Th2 cell differentiation by inhibiting IL-12 production and limiting contact time with CD4 T cells, resulting in Th2-favorable antigen presentation conditions $^{88-94}$. Interestingly, transcriptomic analyses of helminth 
or allergen-conditioned DCs have identified TSLP as a key upstream pathway involved in the upregulation of pro-Th2 OX40L expression. CD301b dermal DCs can also support Th2 cell differentiation, as an immunization with OVA mixed with papain or alum is sufficient to drive Th2 cell polarization ${ }^{95}$. Interestingly, allergen-activated TRPV1 neurons may trigger the migration of CD301 $\mathrm{b}^{+}$DCs to the draining lymph node via substance $\mathrm{P}$ to induce Th2 cell differentiation ${ }^{96}$. Thus, a combination of select DC subsets, pro-Th1 or pro-Th2 adjuvants, PAMPs, and the site(s) of antigen acquisition seem to ultimately determine the resulting Th1 or Th2 response in vivo rather than a $\mathrm{T}$ cell "choice" within the draining lymph node.

\section{The involvement of local ILC populations on determining $\mathrm{T}$ cell differentiation}

ILCs are innate lymphocytes that lack specific antigen receptors but are able to respond to alarmin cytokines in order to closely mirror $\mathrm{T}$ cell subsets in terms of their subsets and cytokine repertoires. As a result, ILCs have drawn interest in how they might regulate the initiation or quality of a Th1/Th2 response in situ. As ILCs have been expertly reviewed elsewhere ${ }^{97-99}$, we will briefly re-introduce them here. ILCs can be divided up into five major subsets: NK cells, which mirror CD8 T cells, express T-bet and Eomes, and produce IFN $\gamma$, Perforin, and Granzyme B; group 1 ILCs (ILC1s), which closely mirror Th1 cells, express T-bet, and produce IFN $\gamma$ and TNF; group 2 ILCs (ILC2s), which closely mirror Th2 cells, express high levels of GATA3, and produce IL-5, IL-13, and IL-9; group 3 ILCs (ILC3s), which closely mirror Th17 cells, express ROR $\gamma$ t (with some of them also expressing T-bet), and produce IL-22 and GM-CSF (also IFN $\gamma$ for T-bet ${ }^{+}$ILC3s); and lymphoid tissue inducer (LTi) cells, which express ROR $\gamma$ t, produce RANK, lymphotoxins, TNF, and IL-17A, and are required for the formation of lymphoid tissues during development. Thus, as one might expect, ILC subsets are active participants during immune responses and have garnered interest in how they might influence the development of Th1 or Th2 immune responses.

\section{The effects of ILC-derived cytokines on Th responses}

So how might ILCs influence the generation of a $\mathrm{T}$ cell response? One obvious way would be via the secretion of pro-Th1 or pro-Th2 cytokines in response to tissue alarmins (Figure 2). As one might expect, type 2 immunity-inducing agents (e.g. helminth products, papain, Der p1, etc.) can disrupt the integrity of the epithelium, resulting in the release of alarmins, including IL-33, IL-25, and TSLP. ILC2s can respond to IL-33 via T1/ST2 (IL-33R) and IL-25 via IL-17RB to locally produce the type 2 cytokines IL-4, IL-5, and IL-13, thereby setting up a pro-Th2 milieu in situ and helping to initiate and maintain a Th2 response ${ }^{17,100}$. With respect to IL-4, while ILC2s are relatively poor IL-4 producers compared to Th2 cells, there is some evidence to suggest that ILC2-derived IL-4 may support Th2 cell differentiation. During $H$. polygyrus infection, it seems that ILC2-derived IL-4 plays an important role in inducing a Th2 response ${ }^{101}$. In addition, it has been shown that other inflammatory mediators, such as the leukotriene LTD4, may induce IL-4 production by ILC $2 \mathrm{~s}^{101-103}$. Furthermore, IL-13 produced by ILC2s may promote the migration of lung DCs into the draining lymph node to initiate Th2 responses $^{104}$. Similarly, in situ production of IL- 4 and IL-13 by ILC2s or Th2 cells may further induce the expression of IL-25 to amplify type 2 immune responses through recruiting more activated ILC $2 \mathrm{~s}^{105}$. Lastly, early production of IL-5 by in situ ILC2s can potentially support a Th2 response via the recruitment of IL-4-producing eosinophils ${ }^{106-110}$. Therefore, the crosstalk between ILC2s and Th2 cells may play an important role in mounting a robust type 2 response, and such crosstalk may also serve as a target for treating chronic type 2 inflammation.

In response to an acute pro-Th1 infectious insult, such as T. gondii or MCMV infection, ILC1s are stimulated by cDC-sourced IL-12 in order to produce IFN $\gamma$ and can help mount a Th1 response. However, one open-ended question considering this paradigm concerns how ILCs and DCs might interact or crosstalk in order to influence the generation of a Th1 or Th2 response. As noted in the preceding section, while $\mathrm{cDC} 1 \mathrm{~s}$ are great at generating a Th1 response, given the right adjuvants TNFR2 ${ }^{+}$cDC2s can also elicit Th1 cells. Depending on the adjuvants and infection route/immunization route involved, the involvement of ILC1s versus ILC2s might differ, as the tissue distributions of both are quite different. Another open-ended question that has not been addressed in the literature concerns how opposed ILCs might respond during a Th1 or Th2 response. For example, the lung is host to a large population of ILC2s and a smaller population of ILC3s and ILC1s, and, as one might expect, ILC2s actively participate in Th2-mediated lung pathologies including allergy. However, what might happen to those ILC2s in the context of a strong Th1 infectious insult such as a viral infection or bacterial pneumonia? Is it possible that the activation status of ILC2s in the lung may determine the severity of SARS-CoV2-infected patients? Thus, while ILCs are active participants in setting up a local pro-Th1 or pro-Th2 environment, there is still much to learn.

\section{The effects of ILC-mediated antigen presentation on Th responses}

Another possible mechanism through which ILCs might affect the Th1/Th2 response is through potential antigen presentation. Unlike MHC-I, which is expressed by almost every cell, the expression of MHC-II is restricted to antigen-presenting cells, and, remarkably enough, some ILC2s and ILC $3 \mathrm{~s}$ are also endowed with the machinery to process and present peptides on MHC-II molecules and are thus potentially able to interact with $\mathrm{T}$ cells via TCR-peptide-MHCII complexes ${ }^{99,111,112}$. Interestingly, ILC2s can stimulate T cells via peptide-loaded MHC-II, and one report demonstrated that the secretion of IL-2 by ILC2s in T cell/ILC2 co-cultures resulted in an expansion of ILC $2 \mathrm{~s}^{112}$. Thus, ILC2s might also be able to influence in situ Th2 responses via antigen presentation. At present, it isn't clear how important this mechanism is in comparison to antigen presentation via professional antigen-presenting DCs.

\section{Alternative differentiation pathways to Th1 \& Th2 cells via Th17 intermediates}

In addition to Th1 and Th2 cells, a third type of CD4 effector $\mathrm{T}$ cell termed Th17 cells are interesting in the context of the Th1/Th2 fate decision owing to their less-committed, plastic 


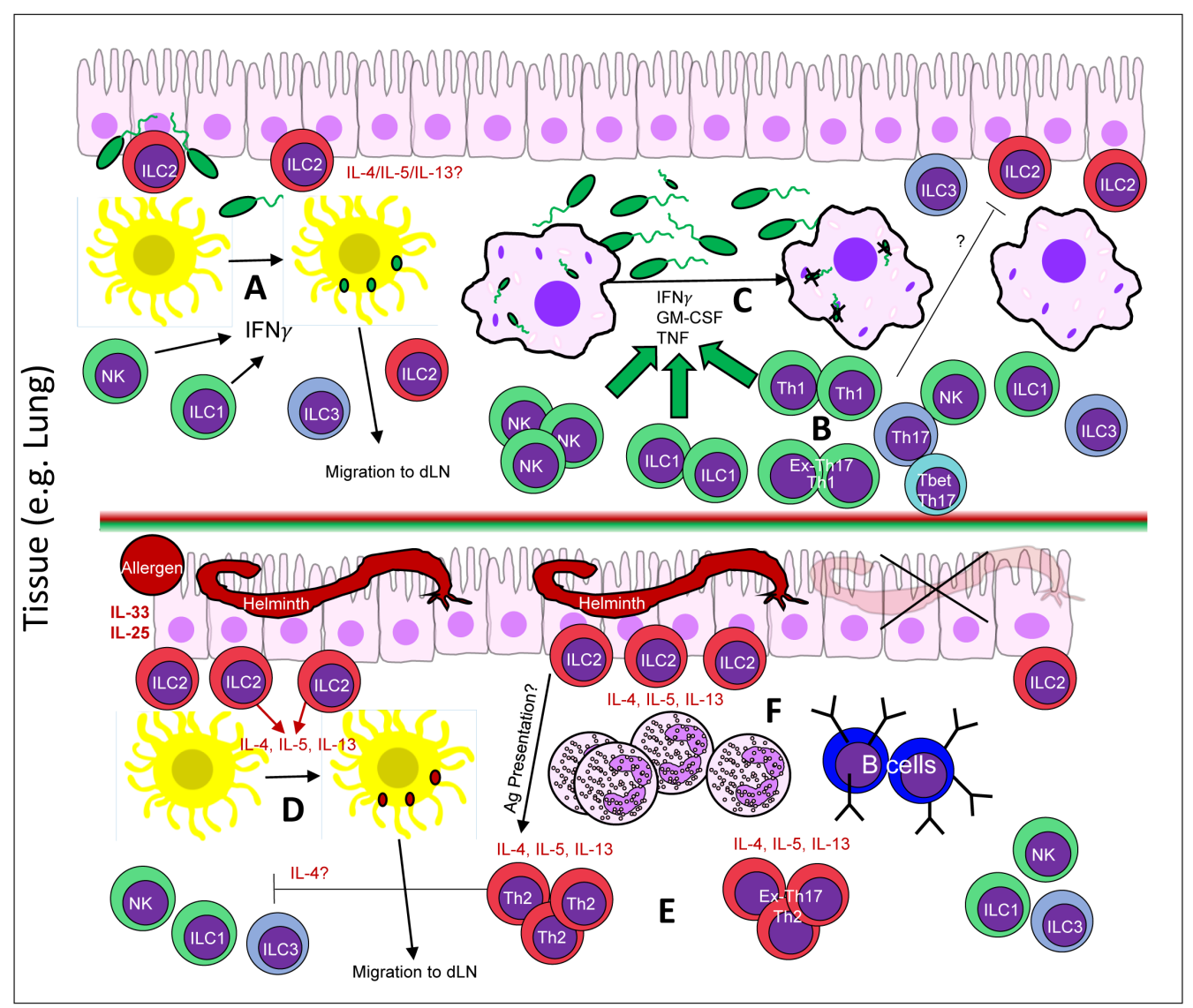

Figure 2. An updated view of the players in situ that help to shape a Th1/Th2 response. Presented here is our updated view of the Th1/Th2 T effector decision in situlin vivo. In response to an immunological insult in a complex tissue, such as the lung, local innate immune cells respond appropriately to guide the downstream selection of Th1 or Th2 cells. In response to a pro-Th1 bacterial infection (A-C), in situ NK cells and ILC1s respond to alarmins to produce IFN $\gamma$ and local dendritic cells acquire bacterial Ags (A). Ag-laden dendritic cells may then travel to the nearest dLN to present bacterial Ags and generate bacterial Ag-specific Th1 cell or a mixed Th17 and Th1 cell response. Bacterial Ag-specific Th1, Th17, T-bet ${ }^{+}$Th1-like Th17, and ex-Th17-Th1-like cells can then home back to the site of infection or Th17 cells can generate T-bet ${ }^{+}$Th1-like Th17/ex-Th17-Th1-like cells in situ (B) in order to coordinate with local NK cells, ILC1 cells, and macrophages to control the bacterial infection (C). The potential antagonistic effects between Th1 cells and lung-resident ILC2s in this context are unclear. In contrast to a pro-Th1 insult, allergen exposure or a helminth infection is able to elicit a Th2 Ag-specific cell response (D-F). In this scenario, a helminth infection is sufficient to drive the production of alarmins (IL-33/IL-25) from the lung epithelium and activate local tissue ILC2s (D). In situ ILC2s can produce IL-4/IL-13 in response and promote helminth Ag-bearing dendritic cells homing to the nearest dLN. Helminth Ag-specific naïve T cells are selected by the Ag-laden dendritic cell and helminth Ag-specific Th2 or a mixture of Th17 and Th2 cells are generated (E). Helminth Ag-specific Th2, Th17, Th2-like Th17 cells, and ex-Th17-Th2-like cells may then home back to the infected tissue in order to work in conjunction with locally recruited and activated eosinophils, B cells, and ILC2s in order to expel or kill the invading helminth (F). Ag, antigen; dLN, draining lymph node; GM-CSF, granulocyte-macrophage colony-stimulating factor; IFN, interferon; IL, interleukin; ILC, innate lymphoid cell; NK, natural killer; Th2, type 2 T helper; Th17, interleukin-17-producing T helper; TNF, tumor necrosis factor.

properties. Briefly, Th17 cells are a bona fide IL-17A/IL-17F/ IL-22-secreting CD4 $\mathrm{T}$ effector cell subset that plays a key role in the defense against opportunistic fungal or bacterial pathogens but may also participate in autoimmune and allergic diseases ${ }^{38}$. Following the discovery of IL-17A-producing CD4 T cells in $2005^{113,114}$, the mechanisms of Th17 polarization were quickly described $^{115-118}$. Conceptually, extracellular bacterial or fungal PAMPs result in antigen-presenting cell-mediated antigen presentation and the production of the pro-inflammatory cytokines
IL-1 $\beta$, IL-6, and IL-23, which drive the generation of Th17 cells in a ROR $\gamma$ t (TCR/NFAT/NFkB/AP-1) and pSTAT3 (IL-6 and IL-23) dependent manner ${ }^{38,119}$. In addition, the master Th17 lineage transcription factor ROR $\gamma$ t can collaborate with other transcription factors, including IRF4, BATF, and Runx1/Runx3, to optimally induce the expression of Th17 lineage genes ${ }^{2,62,120}$. However, following these seminal discoveries, it became readily apparent that Th17 cell-mediated responses can exert both protective and pathogenic effects during immunological challenges, 
suggesting that Th17 cells can be divided into "pathogenic" and "non-pathogenic" subsets. Functionally distinct homeostatic and inflammatory Th17 cells can be found in the intestine ${ }^{121}$. Several putative regulators of Th17 "pathogenicity" have been described, including IL-23, CD5L, REV-ERB $\alpha$, and various environmental factors such as commensal organisms and tissue salinity; however, the precise mechanisms governing the protective/pathogenic switch are still unclear and may involve supplemental non-lineage-related transcription factors ${ }^{122-128}$. To further complicate things, it has become readily apparent that Th17 cells can co-opt T-bet or GATA3 expression to assume aspects of the Th1 or Th2 lineage (termed Th17/Th1 or Th17/ $\mathrm{Th} 2$ cells) or to fully assume a functional Th1 or Th2 phenotype (ex-Th17-Th1-like cell or ex-Th17-Th2-like cell).

\section{When the distinctions between Th17 and Th1 cells blur: Th17/Th1 and ex-Th17-Th1-like cells}

To date, there are several lines of evidence to support the concept that Th17 cells may co-opt aspects of the Th1 lineage or even assume an ex-Th17-Th1-like cell fate in various in vivo contexts. In a study utilizing IL-17A $\mathrm{A}^{+}$Th17 cell fate mapping reporter mice (Il17a $a^{\mathrm{Cre}}$ Rosa26 $6^{\mathrm{eYFP}}$ mice) and mouse models of Th17- and Th1-related inflammation (EAE and subcutaneous immunization with Candida albicans), a population of fate mapped ex-Th17 cells (IL-17A-eYFP ${ }^{+}$cells) was identified ${ }^{129}$. Interestingly, subpopulations of $\mathrm{T}^{-}$bet $^{+} \mathrm{ROR} \gamma \mathrm{t}^{+} \mathrm{IL}-17 \mathrm{~A}^{+}$cells and IFN $\gamma^{+}$IL-17 $\mathrm{A}^{-}$arose amongst the IL-17A fate mapped cells, suggesting that a Th17 cell may generate a mixture of IFN $\gamma^{+}$IL-17A ${ }^{+}$Th17 cells and IFN $\gamma^{+}$IL-17A- ex-Th17-Th1-like cell subpopulations. Furthermore, the generation of IL-17A fate mapped $\mathrm{eYFP}^{+}$cells depends on IL-23-induced expression of T-bet, as an $I l 17 a^{\mathrm{Cre}}$ Rosa $26^{\mathrm{CYFP}} I l 23 r^{--}$variant failed to generate $\mathrm{IFN} \gamma^{+} \mathrm{IL}-17 \mathrm{~A}^{+} \mathrm{eYFP}{ }^{+}$or $\mathrm{IFN} \gamma^{+} \mathrm{IL}-17 \mathrm{~A}^{-} \mathrm{eYFP}^{+}$fate mapped cells. Runx1 together with T-bet plays an important role in the generation of IFN $\gamma$-producing Th17 cells ${ }^{130}$. A similar phenotypic change from Th17 to Th1 cells has also been observed in a model of Helicobacter hepaticus-induced colitis, an in vitro polarized Th17 $\mathrm{T}$ cell transfer $\mathrm{Rag}^{-1-}$ colitis model, and an IL-22 Th17 fate mapping model in the gut, suggesting that Th17 cells are intrinsically plastic and can generate a population of T-bet ${ }^{+} \mathrm{ROR} \gamma \mathrm{t}^{+}$Th1-like Th17 cells and a population of ex-Th17 cells that assumed a Th1 phenotype (ex-Th17-Th1-like cells) ${ }^{131-133}$. In addition, IL-23 was shown by Jain and colleagues to induce Blimp-1 expression within Th17 cells, and Blimp-1 was shown to be necessary for the induction of T-bet-, GM-CSF-, and IFN $\gamma$-expressing Th17 cells within the gut, suggesting that IL-23 along with other transcription factors may synergize to induce a Th1-like phenotype within Th17 cells ${ }^{134}$. However, from a Th1/Th2-centric viewpoint, the later ex-Th17-Th1-like cell population poses an interesting philosophical dilemma: if Th17 cells can generate a subpopulation of cells that are essentially Th1 cells and naïve $\mathrm{T}$ cells can directly differentiate into Th1 cells as well, what, if anything, would distinguish the two in vivo? In addition, are there any meaningful differences between former Th17-derived Th1 cells and de novo Th1 cells? Do they have distinct functionalities in host defense versus in inflammation? While these open questions remain to be addressed in the literature, Th1-like subpopulations of Th17 cells have been observed in various human patient populations, including multiple sclerosis, rheumatoid arthritis, psoriasis, inflammatory bowel disease, and $M$. tuberculosis patients and others, so Th1-like Th17 cells and ex-Th17-Th1-like cells may have some clinical relevance.

\section{Th17 plasticity towards the other fate: Th17/Th2 and ex-Th17-Th2-like cells}

Similarly, there is some limited evidence to suggest that Th17 cells may also assume Th2-like properties in the context of allergic disease. In a study profiling human PBMC CD4 memory cells from atopic asthma patients, Wang and colleagues observed a population of $\mathrm{CD}^{+}{ }^{+} \mathrm{CRTH} 2{ }^{+} \mathrm{CCR}^{+}{ }^{+} \mathrm{T}$ cells that were elevated in allergic asthmatic patients versus healthy controls and co-expressed IL-4, IL-17A, IL-22, IL-5, IL-13, ROR $\gamma$ t, and GATA3, suggesting that a population of Th2-like Th17 cells are generated during the development of atopic asthma and may be associated with the pathology. Interestingly, a similar population of $\mathrm{IL}-4^{\mathrm{GFP}+} \mathrm{IL}-17 \mathrm{~A}^{+}$Th17 cells were isolated from the bronchoalveolar lavage (BAL) fluid and lungs of Aspergillus Orazae + OVA challenged IL-4-GFP knock-in (4Get) mice, suggesting that both mouse and human Th17 cells may assume a partial Th2 phenotype in the context of allergy ${ }^{135}$. Similar results were observed by Irvin and colleagues in a study examining BAL $\mathrm{T}$ cell phenotypes from a different cohort of atopic asthmatic patients. In that study, IL- $4^{+} \mathrm{IL}-17 \mathrm{~A}^{+} \mathrm{GATA} 3{ }^{+} \mathrm{ROR} \gamma \mathrm{t}^{+} \mathrm{T}$ cells were observed and IL- $4^{+} \mathrm{IL}-17 \mathrm{~A}^{+} \mathrm{T}$ cells correlated with eosinophil counts and occurred in the most severe subgroup of asthmatic patients ${ }^{136}$. Together, these observations of Th2-like Th17 cells suggest that Th17 cells may also assume characteristics of Th2 cells and suggest that the formation of ex-Th17-Th2like cells (the Th2 equivalent of ex-Th17-Th1-like cells) may be theoretically feasible in the context of allergy or helminth infections. Indeed, a recent study showed that $\sim 10 \%$ of the IL-17A-IL-4/5/13+ cells in the lung are IL-17A fate mapping positive ${ }^{137}$. Taken together, the available data indicate that close encounters between bona fide Th1/Th2 cells and Th17 plastic approximations of Th1/Th2 cells, which develop through the Th17 intermediate stage, may occur in vivo. While it is likely that the pro-inflammatory cytokines such as IL-1 $\beta$ and IL-6, both of which can be induced even during Th1 and Th2 responses, may determine these alternative differentiation pathways to Th1 and Th2 cells, the precise regulation and contributions of these unconventional Th1/Th2 subsets relative to classical Th1/Th2 cells during immune responses remain an open question (Figure 1).

\section{Conclusion}

In summary, despite the tremendous amount of work that has been accomplished since Mossman and Coffman's seminal Th1/Th2 hypothesis in 1986, there is clearly more to discover about how Th1/Th2 effector fate decisions are made in vivo. While the present work was in no way designed to be all encompassing, we have highlighted some recent advances in the field that have contributed to our understanding of how Th1/Th2 immune responses are initiated and amplified in vivo. Ultimately, the decision to launch or modify the quality of a 
Th1 or Th2 immune response can be distilled down to several variables: 1) the site(s) of antigen encounter and which DC subset(s) acquire and present the antigen(s), 2) which ILC subsets are activated in situ to support the de novo adaptive immune response, 3) which differentiating cytokines are produced by the antigen-presenting DCs within the draining lymph node, 4) whether or not there is Th17 cell involvement to contribute towards the overall Th1/Th2 cell response, and 5) the expression of Th1/Th2 response-modifying transcription factors, such as Bhlhe40 and Bcl11b, etc. New technologies including single cell RNA-Seq ${ }^{138}$ and single cell ATAC-Seq analysis of antigen-specific CD4 $\mathrm{T}$ cells as well as advanced imaging to visualize cell-cell interactions in vivo at different stages during immune responses will greatly help further our understanding of the differentiation process of Th1 and Th2 cells and ultimately contribute to the design of better and precise strategies in treating immunological diseases involving these two important lymphocyte subsets.
1. Mosmann TR, Cherwinski H, Bond MW, et al:: Two types of murine helper T cell clone. I. Definition according to profiles of lymphokine activities and secreted proteins. J Immunol. 1986; 136(7): 2348-57. PubMed Abstract

2. Zhu J: T Helper Cell Differentiation, Heterogeneity, and Plasticity. Cold Spring Harb Perspect Biol. 2018; 10(10): a030338.

PubMed Abstract | Publisher Full Text | Free Full Text

3. Szabo SJ, Sullivan BM, Peng SL, et al:: Molecular mechanisms regulating Th1 immune responses. Annu Rev Immunol. 2003; 21: 713-58. PubMed Abstract | Publisher Full Text

4. Zhu J, Paul WE: CD4 T cells: Fates, functions, and faults. Blood. 2008; 112(5): 1557-69.

PubMed Abstract | Publisher Full Text | Free Full Text

5. Zhu J, Yamane H, Paul WE: Differentiation of effector CD4 T cell populations (*). Annu Rev Immunol. 2010; 28: 445-89. PubMed Abstract | Publisher Full Text | Free Full Text

6. Szabo SJ, Kim ST, Costa GL, et al.: A Novel Transcription Factor, T-bet, Directs Th1 Lineage Commitment. Cell. 2000; 100(6): 655-69. PubMed Abstract | Publisher Full Text

7. Szabo SJ, Sullivan BM, Stemmann C, et al.: Distinct effects of T-bet in TH1 lineage commitment and IFN-gamma production in CD4 and CD8 T cells. Science. 2002; 295(5553): 338-42.

PubMed Abstract | Publisher Full Text | Faculty Opinions Recommendation

8. Lazarevic V, Glimcher LH, Lord GM: T-bet: A bridge between innate and adaptive immunity. Nat Rev Immunol. 2013; 13(11): 777-89.

PubMed Abstract | Publisher Full Text | Free Full Text

9. Lighvani $A A$, Frucht $D M$, Jankovic $D$, et al:: T-bet is rapidly induced by interferongamma in lymphoid and myeloid cells. Proc Natl Acad Sci U S A. 2001; 98(26): 15137-42.

PubMed Abstract | Publisher Full Text | Free Full Text

10. Afkarian M, Sedy JR, Yang J, et al.: T-bet is a STAT1-induced regulator of IL-12R expression in naïve CD4+ T cells. Nat Immunol. 2002; 3(6): 549-57. PubMed Abstract | Publisher Full Text | Faculty Opinions Recommendation

11. Yang Y, Ochando JC, Bromberg JS, et al:: Identification of a distant T-bet enhancer responsive to IL-12/Stat4 and IFNgamma/Stat1 signals. Blood. 2007; 110(7): 2494-500.

PubMed Abstract | Publisher Full Text | Free Full Text

12. Zhu J, Jankovic $\mathrm{D}$, Oler $\mathrm{AJ}$, et al.: The transcription factor T-bet is induced by multiple pathways and prevents an endogenous Th2 cell program during Th1 cell responses. Immunity. 2012; 37(4): 660-73. PubMed Abstract | Publisher Full Text | Free Full Text

13. Hölscher C: The power of combinatorial immunology: IL-12 and IL-12-related dimeric cytokines in infectious diseases. Med Microbiol Immunol. 2004; 193(1) $1-17$

PubMed Abstract | Publisher Full Text

14. Mullen AC, High FA, Hutchins AS, et al:: Role of T-bet in commitment of TH1 cells before IL-12-dependent selection. Science. 2001; 292(5523): 1907-10. PubMed Abstract | Publisher Full Text

15. Lambrecht $\mathrm{BN}, \mathrm{Hammad} \mathrm{H}$ : Biology of lung dendritic cells at the origin of asthma. Immunity. 2009; 31(3): 412-24. PubMed Abstract | Publisher Full Text

16. Licona-Limón P, Kim LK, Palm NW, et al:: TH2, allergy and group 2 innate lymphoid cells. Nat Immunol. 2013; 14(6): 536-42. PubMed Abstract | Publisher Full Text

17. Zhu J: T helper $\mathbf{2}$ (Th2) cell differentiation, type $\mathbf{2}$ innate lymphoid cell (ILC2) development and regulation of interleukin-4 (IL-4) and IL-13 production. Cytokine. 2015; 75(1): 14-24.

PubMed Abstract | Publisher Full Text | Free Full Text

18. Walker JA, McKenzie ANJ: $\mathbf{T}_{\mathrm{H}} \mathbf{2}$ cell development and function. Nat Rev Immunol. 2018; 18(2): 121-133.

PubMed Abstract | Publisher Full Text | Faculty Opinions Recommendation

19. P Paul WE, Zhu J: How are $\mathbf{T}(\mathbf{H}) 2$-type immune responses initiated and amplified? Nat Rev Immunol. 2010; 10(4): 225-35.

PubMed Abstract | Publisher Full Text | Free Full Text |

Faculty Opinions Recommendation

20. Zheng Wp, Flavell RA: The Transcription Factor GATA-3 Is Necessary and Sufficient for Th2 Cytokine Gene Expression in CD4 T Cells. Cell. 1997; 89(4): 587-96.

PubMed Abstract | Publisher Full Text

21. Zhang $\mathrm{DH}$, Cohn L, Ray $\mathrm{P}$, et al:: Transcription factor GATA-3 is differentially expressed in murine Th1 and Th2 cells and controls Th2-specific expression of the interleukin-5 gene. J Biol Chem. 1997; 272(34): 21597-603. PubMed Abstract | Publisher Full Text

22. Zhu J, Min B, Hu-Li J, et al:: Conditional deletion of Gata3 shows its essential function in $\mathrm{T}(\mathrm{H}) 1-\mathrm{T}(\mathrm{H}) 2$ responses. Nat Immunol. 2004; 5(11): 1157-65. PubMed Abstract | Publisher Full Text

23. Pai SY, Truitt ML, Ho IC: GATA-3 deficiency abrogates the development and maintenance of T helper type 2 cells. Proc Natl Acad Sci U S A. 2004; 101(7): 1993-8.

PubMed Abstract | Publisher Full Text | Free Full Text

24. Ho IC, Tai TS, Pai SY: GATA3 and the T-cell lineage: Essential functions before and after T-helper-2-cell differentiation. Nat Rev Immunol. 2009; 9(2): 125-35. PubMed Abstract | Publisher Full Text | Free Full Text

25. Wei G, Abraham BJ, Yagi R, et al:: Genome-wide analyses of transcription factor GATA3-mediated gene regulation in distinct T cell types. Immunity. 2011; 35(2): 299-311.

PubMed Abstract | Publisher Full Text | Free Full Text |

Faculty Opinions Recommendation

26. Yamane H, Zhu J, Paul WE: Independent roles for IL-2 and GATA-3 in stimulating naive $\mathrm{CD}^{+} \mathrm{T}$ cells to generate a Th2-inducing cytokine environment. J Exp Med. 2005; 202(6): 793-804.

PubMed Abstract | Publisher Full Text | Free Full Text

27. Hosken NA, Shibuya K, Heath AW, et al:: The effect of antigen dose on CD4+ helper cell phenotype development in a $T$ cell receptor-alpha beta-transgenic model. J Exp Med. 1995; 182(5): 1579-84.

PubMed Abstract | Publisher Full Text | Free Full Text

28. Brogdon JL, Leitenberg D, Bottomly K: The potency of TCR signaling differentially regulates NFATc/p activity and early IL-4 transcription in naive CD4 ${ }^{+}$T cells. J Immunol. 2002; 168(8): 3825-32.

PubMed Abstract | Publisher Full Text

29. Bhattacharyya ND, Feng CG: Regulation of T Helper Cell Fate by TCR Signal Strength. Front Immunol. 2020; 11: 624. PubMed Abstract | Publisher Full Text | Free Full Text | Faculty Opinions Recommendation

30. Yamashita M, Ukai-Tadenuma M, Kimura M, et al:: Identification of a conserved GATA3 response element upstream proximal from the interleukin-13 gene locus. J Biol Chem. 2002; 277(44): 42399-408. PubMed Abstract | Publisher Full Text

31. Tanaka S, Motomura Y, Suzuki Y, et al:: The enhancer HS2 critically regulates GATA-3-mediated I/4 transcription in T(H)2 cells. Nat Immunol. 2011; 
12(1): 77-85.

PubMed Abstract | Publisher Full Text | Faculty Opinions Recommendation

32. U Usui T, Preiss JC, Kanno Y, et al:: T-bet regulates Th1 responses through essential effects on GATA-3 function rather than on IFNG gene acetylation and transcription. J Exp Med. 2006; 203(3): 755-66.

PubMed Abstract | Publisher Full Text | Free Full Text |

Faculty Opinions Recommendation

33. Hwang ES, Szabo SJ, Schwartzberg PL, et al:: T helper cell fate specified by kinase-mediated interaction of T-bet with GATA-3. Science. 2005; 307(5708): 430-3.

PubMed Abstract | Publisher Full Text | Faculty Opinions Recommendation

34. Jenner RG, Townsend MJ, Jackson I, et al:: The transcription factors T-bet and GATA-3 control alternative pathways of T-cell differentiation through a shared set of target genes. Proc Natl Acad Sci U S A. 2009; 106(42): 17876-81. PubMed Abstract | Publisher Full Text | Free Full Text

35. Kanhere A, Hertweck A, Bhatia U, et al:: T-bet and GATA3 orchestrate Th1 and Th2 differentiation through lineage-specific targeting of distal regulatory elements. Nat Commun. 2012; 3: 1268.

PubMed Abstract | Publisher Full Text | Free Full Text

36. Usui T, Nishikomori R, Kitani A, et al:: GATA-3 suppresses Th1 development by downregulation of Stat 4 and not through effects on IL-12Rbeta2 chain or T-bet. Immunity. 2003; 18(3): 415-28.

PubMed Abstract | Publisher Full Tex

37. Yagi R, Junttila IS, Wei G, et al.: The transcription factor GATA3 actively represses RUNX3 protein-regulated production of interferon-gamma. Immunity. 2010; 32(4): 507-17.

PubMed Abstract | Publisher Full Text | Free Full Text |

Faculty Opinions Recommendation

38. Korn T, Bettelli E, Oukka M, et al.: IL-17 and Th17 Cells. Annu Rev Immunol. 2009; 27: $485-517$

PubMed Abstract | Publisher Full Text

39. Cannons JL, Lu KT, Schwartzberg PL: T follicular helper cell diversity and plasticity. Trends Immunol. 2013; 34(4): 200-7.

PubMed Abstract | Publisher Full Text | Free Full Text

40. Sakaguchi S, Vignali DAA, Rudensky AY, et al.: The plasticity and stability of regulatory T cells. Nat Rev Immunol. 2013; 13(6): 461-7. PubMed Abstract | Publisher Full Text

41. Crotty S: $\mathbf{T}$ follicular helper cell differentiation, function, and roles in disease. Immunity. 2014; 41(4): 529-42.

PubMed Abstract | Publisher Full Text | Free Full Text

42. Nhevach EM: Foxp3 + T Regulatory Cells: Still Many Unanswered Questions-A Perspective After 20 Years of Study. Front Immunol. 2018; 9: 1048. PubMed Abstract | Publisher Full Text | Free Full Text | Faculty Opinions Recommendation

43. Hilligan KL, Ronchese F: Antigen presentation by dendritic cells and their instruction of $\mathrm{CD}_{4}+\mathrm{T}$ helper cell responses. Cell Mol Immunol. 2020; 17(6) 587-99.

PubMed Abstract | Publisher Full Text | Free Full Text |

Faculty Opinions Recommendation

44. C Song W, Craft J: T follicular helper cell heterogeneity: Time, space, and function. Immunol Rev. 2019; 288(1): 85-96.

PubMed Abstract | Publisher Full Text | Free Full Text | Faculty Opinions Recommendation

45. N Ruterbusch M, Pruner KB, Shehata L, et al.: In Vivo CD + T Cell Differentiation and Function: Revisiting the Th1/Th2 Paradigm. Annu Rev Immunol. 2020; 38: 705-25.

PubMed Abstract | Publisher Full Text | Faculty Opinions Recommendation

46. Yu F, Sharma S, Jankovic D, et al:: The transcription factor Bhlhe40 is a switch of inflammatory versus antiinflammatory Th1 cell fate determination. J Exp Med. 2018; 215(7): 1813-21.

PubMed Abstract | Publisher Full Text | Free Full Tex

47. Huynh JP, Lin CC, Kimmey JM, et al:: Bhlhe40 is an essential repressor of IL-10 during Mycobacterium tuberculosis infection. J Exp Med. 2018; 215(7): 1823-38.

PubMed Abstract | Publisher Full Text | Free Full Text |

Faculty Opinions Recommendation

48. Jarjour NN, Bradstreet TR, Schwarzkopf EA, et al:: BHLHE ${ }_{4}$ O Promotes TH 2 Cell-Mediated Antihelminth Immunity and Reveals Cooperative CSF2RB Family Cytokines. J Immunol. 2020; 204(4): 923-32. PubMed Abstract | Publisher Full Text | Free Full Text | Faculty Opinions Recommendation

49. C Li L, Leid M, Rothenberg EV: An early T cell lineage commitment checkpoint dependent on the transcription factor Bcl11b. Science. 2010; 329(5978): 89-93. PubMed Abstract | Publisher Full Text | Free Full Text | Faculty Opinions Recommendation

50. Inoue J, Kanefuji T, Okazuka K, et al:: Expression of TCR alpha beta partly rescues developmental arrest and apoptosis of alpha beta T cells in Bc/11b-/mice. J Immunol. 2006; 176(10): 5871-9. PubMed Abstract | Publisher Full Text
51. Albu DI, Feng D, Bhattacharya $\mathrm{D}$, et al.: $\mathrm{BCL} 11 \mathrm{~B}$ is required for positive selection and survival of double-positive thymocytes. J Exp Med. 2007; 204(12): 3003-15.

PubMed Abstract | Publisher Full Text | Free Full Text

52. Avram D, Califano D: The multifaceted roles of Bcl11b in thymic and peripheral T cells: Impact on immune diseases. J Immunol. 2014; 193(5): 2059-65.

PubMed Abstract | Publisher Full Text | Free Full Text

53. L Li P, Burke S, Wang J, et al.: Reprogramming of T cells to natural killer-like cells upon Bcl11b deletion. Science. 2010; 329(5987): 85-9.

PubMed Abstract | Publisher Full Text | Free Full Text |

Faculty Opinions Recommendation

54. Califano D, Cho JJ, Uddin MN, et al.: Transcription Factor Bcl11b Controls Identity and Function of Mature Type 2 Innate Lymphoid Cells. Immunity. 2015; 43(2): 354-68

PubMed Abstract | Publisher Full Text | Free Full Text

55. Walker JA, Oliphant CJ, Englezakis A, et al.: Bcl11b is essential for group 2 innate lymphoid cell development. J Exp Med. 2015; 212(6): 875-82. PubMed Abstract | Publisher Full Text | Free Full Text

56. Yu Y, Wang C, Clare $\mathrm{S}$, et al.: The transcription factor Bcl11b is specifically expressed in group 2 innate lymphoid cells and is essential for their development. J Exp Med. 2015; 212(6): 865-74

PubMed Abstract | Publisher Full Text | Free Full Text

57. Zhong C, Zhu J: Bcl11b drives the birth of ILC2 innate lymphocytes. J Exp Med. 2015; 212(6): 828

PubMed Abstract | Publisher Full Text | Free Full Text

58. Fang $\mathrm{D}, \mathrm{Cui} \mathrm{K}, \mathrm{Hu}$ G, et al.: Bcl11b, a novel GATA3-interacting protein, suppresses Th1 while limiting Th2 cell differentiation. J Exp Med. 2018; 215(5): 1449-62.

PubMed Abstract | Publisher Full Text | Free Full Text

59. - Lorentsen $\mathrm{KJ}$, Cho JJ, Luo X, et al.: Bcl11b is essential for licensing Th2 differentiation during helminth infection and allergic asthma. Nat Commun. 2018; 9(1): 1679.

PubMed Abstract | Publisher Full Text | Free Full Text |

Faculty Opinions Recommendation

60. Califano D, Sweeney KJ, Le H, et al:: Diverting T helper cell trafficking through increased plasticity attenuates autoimmune encephalomyelitis. $J$ Clin Invest. 2014; 124(1): 174-87.

PubMed Abstract | Publisher Full Text | Free Full Text

61. Henriksson J, Chen X, Gomes T, et al:: Genome-wide CRISPR Screens in T Helper Cells Reveal Pervasive Crosstalk between Activation and Differentiation. Cell. 2019; 176(4): 882-896.e18

PubMed Abstract | Publisher Full Text | Free Full Text |

Faculty Opinions Recommendation

62. Ciofani M, Madar A, Galan C, et al:: A validated regulatory network for Th17 cell specification. Cell. 2012; 151(2): 289-303.

PubMed Abstract | Publisher Full Text | Free Full Text

63. Ren M, Kazemian M, Zheng M, et al:: Transcription factor $\mathbf{p} 73$ regulates Th1 differentiation. Nat Commun. 2020; 11(1): 1475.

PubMed Abstract | Publisher Full Text | Free Full Text |

Faculty Opinions Recommendation

64. He K, Hettinga A, Kale SL, et al:: Blimp-1 is essential for allergen-induced asthma and Th2 cell development in the lung. J Exp Med. 2020; 217(7): e20190742.

PubMed Abstract | Publisher Full Text | Free Full Text |

Faculty Opinions Recommendation

65. Granot T, Senda T, Carpenter DJ, et al.: Dendritic Cells Display Subset and Tissue-Specific Maturation Dynamics over Human Life. Immunity. 2017; 46(3): 504-15.

PubMed Abstract | Publisher Full Text | Free Full Text

66. Anderson DA 3rd, Dutertre CA, Ginhoux F, et al.: Genetic models of human and mouse dendritic cell development and function. Nat Rev Immunol. 2021; 21(2): 101-115.

PubMed Abstract | Publisher Full Text | Faculty Opinions Recommendation

67. N Mashayekhi M, Sandau MM, Dunay IR, et al.: CD8 $\alpha(+)$ dendritic cells are the critical source of interleukin-12 that controls acute infection by Toxoplasma gondii tachyzoites. Immunity. 2011; 35(2): 249-59. PubMed Abstract | Publisher Full Text | Free Full Text | Faculty Opinions Recommendation

68. Ruffell B, Chang-Strachan D, Chan V, et al.: Macrophage IL-10 blocks CD8 ${ }^{+} \mathbf{T}$ cell-dependent responses to chemotherapy by suppressing IL-12 expression in intratumoral dendritic cells. Cancer Cell. 2014; 26(5): 623-37.

PubMed Abstract | Publisher Full Text | Free Full Text

69. Martínez-López M, Iborra S, Conde-Garrosa R, et al:: Batf3-dependent CD103+ dendritic cells are major producers of IL-12 that drive local Th1 immunity against Leishmania major infection in mice. Eur J Immunol. 2015; 45(1): 119-29. PubMed Abstract | Publisher Full Text | Free Full Text

70. Maldonado-López R, de Smedt T, Michel P, et al.: CD8alpha ${ }^{+}$and CD8alpha subclasses of dendritic cells direct the development of distinct $T$ helper cells in vivo. J Exp Med. 1999; 189(3): 587-92.

PubMed Abstract | Publisher Full Text | Free Full Text 
71. Everts B, Tussiwand R, Dreesen L, et al.: Migratory CD103+ dendritic cells suppress helminth-driven type 2 immunity through constitutive expression of IL-12. J Exp Med. 2016; 213(1): 35-51. PubMed Abstract | Publisher Full Text | Free Full Text

72. Conejero L, Khouili SC, Martínez-Cano S, et al:: Lung $\mathrm{CD}_{103^{+}}$dendritic cells restrain allergic airway inflammation through IL-12 production. JCl Insight. 2017; 2(10): e90420.

PubMed Abstract | Publisher Full Text | Free Full Text

73. Igyártó BZ, Haley K, Ortner D, et al:: Skin-resident murine dendritic cell subsets promote distinct and opposing antigen-specific $\mathrm{T}$ helper cell responses. Immunity. 2011; 35(2): 260-72.

PubMed Abstract | Publisher Full Text | Free Full Text | Faculty Opinions Recommendation

74. Luda KM, Joeris T, Persson EK, et al:: IRF8 Transcription-Factor-Dependent Classical Dendritic Cells Are Essential for Intestinal T Cell Homeostasis. Immunity. 2016; 44(4): 860-74.

PubMed Abstract | Publisher Full Text

75. Muzaki ARBM, Tetlak P, Sheng J, et al.: Intestinal CD103(+)CD11b(-) dendritic cells restrain colitis via IFN- $\gamma$-induced anti-inflammatory response in epithelia cells. Mucosal Immunol. 2016; 9(2): 336-51.

PubMed Abstract | Publisher Full Text | Free Full Text

76. Demiri M, Müller-Luda K, Agace WW, et al.: Distinct DC subsets regulate adaptive Th1 and 2 responses during Trichuris muris infection. Parasite Immunol. 2017; 39(10).

PubMed Abstract | Publisher Full Text

77. Arnold IC, Zhang X, Artola-Boran M, et al.: BATF3-dependent dendritic cells drive both effector and regulatory $\mathrm{T}$-cell responses in bacterially infected tissues. PLOS Pathog. 2019; 15(6): e1007866. PubMed Abstract | Publisher Full Text | Free Full Text | Faculty Opinions Recommendation

78. Kawabe $\mathrm{T}$, Jankovic $\mathrm{D}$, Kawabe $\mathrm{S}$, et al:: Memory-phenotype $\mathrm{CD}_{4}+\mathrm{T}$ cells spontaneously generated under steady-state conditions exert innate $\mathrm{T}_{\mathrm{H}}$ 1-like effector function. Sci Immunol. 2017; 2(12): eaam9304. PubMed Abstract | Publisher Full Text | Free Full Text

79. Nakano $\mathrm{H}$, Lin $\mathrm{KL}$, Yanagita $\mathrm{M}$, et al:: Blood-derived inflammatory dendritic cells in lymph nodes stimulate acute $\mathrm{T}$ helper type 1 immune responses. Nat Immunol. 2009; 10(4): 394-402.

PubMed Abstract | Publisher Full Text | Free Full Text

80. Flores-Langarica A, Marshall JL, Bobat S, et al:: T-zone localized monocytederived dendritic cells promote Th1 priming to Salmonella. Eur J Immunol. 2011; 41(9): 2654-65.

PubMed Abstract | Publisher Full Text

81. Goldszmid RS, Caspar P, Rivollier A, et al.: NK cell-derived interferon- $\gamma$ orchestrates cellular dynamics and the differentiation of monocytes into dendritic cells at the site of infection. Immunity. 2012; 36(6): 1047-59. PubMed Abstract | Publisher Full Text | Free Full Text

82. de Koker S, van Hoecke L, de Beuckelaer A, et al.: Inflammatory monocytes regulate Th1 oriented immunity to $\mathrm{CpG}$ adjuvanted protein vaccines through production of IL-12. Sci Rep. 2017; 7(1): 5986.

PubMed Abstract | Publisher Full Text | Free Full Text

83. Bosteels C, Neyt K, Vanheerswynghels M, et al.: Inflammatory Type $\mathbf{2}$ cDCs Acquire Features of $\mathrm{cDC1} 1 \mathrm{~s}$ and Macrophages to Orchestrate Immunity to Respiratory Virus Infection. Immunity. 2020; 52(6): 1039-1056.e9. PubMed Abstract | Publisher Full Text | Free Full Text | Faculty Opinions Recommendation

84. Mansouri S, Patel S, Katikaneni DS, et al.: Immature lung TNFR2 conventional DC 2 subpopulation activates moDCs to promote cyclic di-GMP mucosal adjuvant responses in vivo. Mucosal Immunol. 2019; 12(1): 277-89. PubMed Abstract | Publisher Full Text | Free Full Text | Faculty Opinions Recommendation

85. Gao Y, Nish SA, Jiang R, et al.: Control of T helper 2 responses by transcription factor IRF4-dependent dendritic cells. Immunity. 2013; 39(4): 722-32.

PubMed Abstract | Publisher Full Text | Free Full Text | Faculty Opinions Recommendation

86. Williams JW, Tjota MY, Clay BSI, et al:: Transcription factor IRF4 drives dendritic cells to promote Th2 differentiation. Nat Commun. 2013; 4: 2990. PubMed Abstract | Publisher Full Text | Free Full Text

87. Tussiwand R, Everts B, Grajales-Reyes GE, et al:: KIf4 expression in conventional dendritic cells is required for $\mathrm{T}$ helper 2 cell responses. Immunity. 2015; 42(5): 916-28.

PubMed Abstract | Publisher Full Text | Free Full Text

88. Mayer JU, Demiri M, Agace WW, et al.: Different populations of CD11b + dendritic cells drive Th2 responses in the small intestine and colon. Nat Commun. 2017; 8: 15820

PubMed Abstract | Publisher Full Text | Free Full Text

89. MacDonald AS, Straw AD, Bauman B, et al:: CD8- dendritic cell activation status plays an integral role in influencing Th2 response development. $J$ Immunol. 2001; 167(4): 1982-8 PubMed Abstract | Publisher Full Text

90. Cde Jong EC, Vieira PL, Kalinski P, et al.: Microbial compounds selectively induce Th1 cell-promoting or Th2 cell-promoting dendritic cells in vitro with diverse th cell-polarizing signals. J Immunol. 2002; 168(4): 1704-9. PubMed Abstract | Publisher Full Text | Faculty Opinions Recommendation

91. Deverts B, Perona-Wright G, Smits HH, et al.: Omega-1, a glycoprotein secreted by Schistosoma mansoni eggs, drives Th2 responses. J Exp Med. 2009; 206(8): 1673-80.

PubMed Abstract | Publisher Full Text | Free Full Text | Faculty Opinions Recommendation

92. N Steinfelder S, Andersen JF, Cannons JL, et al.: The major component in schistosome eggs responsible for conditioning dendritic cells for Th2 polarization is a T2 ribonuclease (omega-1). J Exp Med. 2009; 206(8): 1681-90. PubMed Abstract | Publisher Full Text | Free Full Text |

Faculty Opinions Recommendation

93. Connor LM, Tang SC, Camberis M, et al:: Helminth-conditioned dendritic cells prime $\mathrm{CD4}^{+} \mathrm{T}$ cells to IL-4 production in vivo. J Immunol. 2014; 193(6): 2709-17. PubMed Abstract | Publisher Full Text

94. Vvan Panhuys N, Klauschen F, Germain RN: T-cell-receptor-dependent signal intensity dominantly controls CD4(+) T cell polarization In Vivo. Immunity. 2014 41(1): 63-74.

PubMed Abstract | Publisher Full Text | Free Full Text | Faculty Opinions Recommendation

95. Kumamoto $\mathrm{Y}$, Linehan M, Weinstein JS, et al.: CD301 b+ dermal dendritic cells drive T helper 2 cell-mediated immunity. Immunity. 2013; 39(4): 733-43. PubMed Abstract | Publisher Full Text | Free Full Text

96. Perner C, Flayer CH, Zhu X, et al:: Substance P Release by Sensory Neurons Triggers Dendritic Cell Migration and Initiates the Type-2 Immune Response to Allergens. Immunity. 2020; 53(5): 1063-1077.e7. PubMed Abstract | Publisher Full Text | Free Full Text Faculty Opinions Recommendation

97. Artis D, Spits H: The biology of innate lymphoid cells. Nature. 2015; $\mathbf{5 1 7 ( 7 5 3 4 ) :}$ 293-301.

PubMed Abstract | Publisher Full Text

98. Gurram RK, Zhu J: Orchestration between ILC2s and Th2 cells in shaping type 2 immune responses. Cell Mol Immunol. 2019; 16(3): 225-35. PubMed Abstract | Publisher Full Text | Free Full Text

99. N Klose CSN, Artis D: Innate lymphoid cells control signaling circuits to regulate tissue-specific immunity. Cell Res. 2020; 30(6): 475-91. PubMed Abstract | Publisher Full Text | Free Full Text | Faculty Opinions Recommendation

100. Kabata H, Moro K, Koyasu S, et al.: The group 2 innate lymphoid cell (ILC2) regulatory network and its underlying mechanisms. Immunol Rev. 2018; 286(1): 37-52.

PubMed Abstract | Publisher Full Text | Faculty Opinions Recommendation

101. Pelly VS, Kannan Y, Coomes SM, et al.: IL-4-producing ILC2s are required for the differentiation of $\mathrm{T}_{\mathrm{H}} 2$ cells following Heligmosomoides polygyrus infection. Mucosal Immunol. 2016; 9(6): 1407-17. PubMed Abstract | Publisher Full Text | Free Full Text

102. Doherty TA, Khorram N, Lund S, et al.: Lung type 2 innate lymphoid cells express cysteinyl leukotriene receptor 1 , which regulates TH2 cytokine production. J Allergy Clin Immunol. 2013; 132(1): 205-13. PubMed Abstract | Publisher Full Text | Free Full Text

103. Salimi $\mathrm{M}$, Stöger L, Liu W, et al:: Cysteinyl leukotriene $\mathbf{E}_{4}$ activates human group 2 innate lymphoid cells and enhances the effect of prostaglandin $D$ and epithelial cytokines. J Allergy Clin Immunol. 2017; 140(4): 1090-1100.e11. PubMed Abstract | Publisher Full Text | Free Full Text

104. N Halim TYF, Steer CA, Mathä L, et al.: Group 2 innate lymphoid cells are critical for the initiation of adaptive $\mathrm{T}$ helper $\mathbf{2}$ cell-mediated allergic lung inflammation. Immunity. 2014; 40(3): 425-35.

PubMed Abstract | Publisher Full Text | Free Full Text |

Faculty Opinions Recommendation

105. Non Moltke J, Ji M, Liang HE, et al:: Tuft-cell-derived IL-25 regulates an intestinal ILC2-epithelial response circuit. Nature. 2016; 529(7585): 221-5. PubMed Abstract | Publisher Full Text | Free Full Text | Faculty Opinions Recommendation

106. Mogbel R, Ying S, Barkans J, et al.: Identification of messenger RNA for IL-4 in human eosinophils with granule localization and release of the translated product. J Immunol. 1995; 155(10): 4939-47. PubMed Abstract

107. Nonaka M, Nonaka R, Woolley $\mathrm{K}$, et al.: Distinct immunohistochemical localization of IL-4 in human inflamed airway tissues. IL-4 is localized to eosinophils in vivo and is released by peripheral blood eosinophils. $J$ Immunol. 1995; 155(6): 3234-44. PubMed Abstract

108. Möller GM, de Jong TA, van der Kwast TH, et al: Immunolocalization of interleukin-4 in eosinophils in the bronchial mucosa of atopic asthmatics. $A m$ J Respir Cell Mol Biol. 1996; 14(5): 439-43. PubMed Abstract | Publisher Full Text

109. Nakajima H, Gleich GJ, Kita H: Constitutive production of IL-4 and IL-10 and stimulated production of IL-8 by normal peripheral blood eosinophils. $J$ Immunol. 1996; 156(12): 4859-66.

PubMed Abstract 
110. Davoine F, Lacy P: Eosinophil cytokines, chemokines, and growth factors: Emerging roles in immunity. Front Immunol. 2014; 5: 570. PubMed Abstract | Publisher Full Text | Free Full Text

111. Hepworth MR, Monticelli LA, Fung TC, et al.: Innate lymphoid cells regulate CD4 ${ }^{+}$T-cell responses to intestinal commensal bacteria. Nature. 2013; 498(7542): 113-7.

PubMed Abstract | Publisher Full Text | Free Full Text | Faculty Opinions Recommendation

112. Oliphant CJ, Hwang YY, Walker JA, et al:: MHCll-mediated dialog between group 2 innate lymphoid cells and CD4(+) T cells potentiates type 2 immunity and promotes parasitic helminth expulsion. Immunity. 2014; 41(2): 283-95. PubMed Abstract | Publisher Full Text | Free Full Text | Faculty Opinions Recommendation

113. N Park H, Li Z, Yang XO, et al:: A distinct lineage of CD4 T cells regulates tissue inflammation by producing interleukin 17. Nat Immunol. 2005; 6(11) 1133-41.

PubMed Abstract | Publisher Full Text | Free Full Text |

Faculty Opinions Recommendation

114. Harrington LE, Hatton RD, Mangan PR, et al.: Interleukin 17-producing CD4 effector $\mathrm{T}$ cells develop via a lineage distinct from the $\mathrm{T}$ helper type 1 and 2 lineages. Nat Immunol. 2005; 6(11): 1123-32.

PubMed Abstract | Publisher Full Text | Faculty Opinions Recommendation

115. C Bettelli E, Carrier Y, Gao W, et al:: Reciprocal developmental pathways for the generation of pathogenic effector $\mathrm{T}_{\mathrm{H}} 17$ and regulatory T cells. Nature. 2006; 441(7090): 235-8.

PubMed Abstract | Publisher Full Text | Faculty Opinions Recommendation

116. Langrish CL, Chen Y, Blumenschein WM, et al.: IL-23 drives a pathogenic T cell population that induces autoimmune inflammation. J Exp Med. 2005; 201(2): 233-40.

PubMed Abstract | Publisher Full Text | Free Full Text | Faculty Opinions Recommendation

117. Mangan PR, Harrington LE, O'Quinn DB, et al:: Transforming growth factorbeta induces development of the $T(H) 17$ lineage. Nature. 2006; 441(7090): 231-4.

PubMed Abstract | Publisher Full Text | Faculty Opinions Recommendation

118. Veldhoen M, Hocking RJ, Atkins CJ, et al:: TGFbeta in the context of an inflammatory cytokine milieu supports de novo differentiation of IL-17producing T cells. Immunity. 2006; 24(2): 179-89. PubMed Abstract | Publisher Full Text | Faculty Opinions Recommendation

119. Nivanov II, McKenzie BS, Zhou L, et al.: The orphan nuclear receptor RORgammat directs the differentiation program of proinflammatory IL-17+ helper cells. Cell. 2006; 126(6): 1121-33. PubMed Abstract | Publisher Full Text | Faculty Opinions Recommendation

120. Lazarevic $\mathrm{V}$, Chen $\mathrm{X}$, Shim $\mathrm{JH}$, et al: $\mathrm{T}$-bet represses $\mathrm{T}(\mathrm{H}) 17$ differentiation by preventing Runx1-mediated activation of the gene encoding ROR t. Nat Immunol. 2011; 12(1): 96-104. PubMed Abstract | Publisher Full Text | Free Full Text

121. O Omenetti S, Bussi C, Metidji A, et al:: The Intestine Harbors Functionally Distinct Homeostatic Tissue-Resident and Inflammatory Th17 Cells. Immunity. 2019; 51(1): 77-89.e6.

PubMed Abstract | Publisher Full Text | Free Full Text |

Faculty Opinions Recommendation

122. N Ivanov II, Atarashi K, Manel N, et al:: Induction of intestinal Th17 cells by segmented filamentous bacteria. Cell. 2009; 139(3): 485-98. PubMed Abstract | Publisher Full Text | Free Full Text | Faculty Opinions Recommendation

123. Kleinewietfeld M, Manzel A, Titze J, et al:: Sodium chloride drives autoimmune disease by the induction of pathogenic $\mathrm{T}_{\mathrm{H}} 17$ cells. Nature. 2013; 496(7446): 518-22

PubMed Abstract | Publisher Full Text | Free Full Text | Faculty Opinions Recommendation

124. W Wang C, Yosef N, Gaublomme J, et al.: CD5L/AIM Regulates Lipid
Biosynthesis and Restrains Th17 Cell Pathogenicity. Cell. 2015; 163(6) 1413-27.

PubMed Abstract | Publisher Full Text | Free Full Text |

Faculty Opinions Recommendation

125. Wilck N, Matus MG, Kearney SM, et al.: Salt-responsive gut commensal modulates $\mathrm{T}_{H} 17$ axis and disease. Nature. 2017; 551(7682): 585-9. PubMed Abstract | Publisher Full Text | Free Full Text | Faculty Opinions Recommendation

126. Amir M, Chaudhari S, Wang R: REV-ERB $\alpha$ Regulates $\mathrm{T}_{H} 17$ Cell Development and Autoimmunity. Cell Rep. 2018; 25(13): 3733-3749.e8. PubMed Abstract | Publisher Full Text | Free Full Text | Faculty Opinions Recommendation

127. Bacher P, Hohnstein T, Beerbaum E, et al:: Human Anti-fungal Th17 Immunity and Pathology Rely on Cross-Reactivity against Candida albicans. Cell. 2019; 176(6): 1340-1355.e15.

PubMed Abstract | Publisher Full Text | Faculty Opinions Recommendation

128. Britton GJ, Contijoch EJ, Mogno I, et al.: Microbiotas from Humans with Inflammatory Bowel Disease Alter the Balance of Gut Th17 and ROR $\gamma \mathbf{t}^{+}$ Regulatory T Cells and Exacerbate Colitis in Mice. Immunity. 2019; 50(1): 212-224.e4.

PubMed Abstract | Publisher Full Text | Free Full Text | Faculty Opinions Recommendation

129. Hirota K, Duarte JH, Veldhoen M, et al:: Fate mapping of IL-17-producing T cells in inflammatory responses. Nat Immunol. 2011; 12(3): 255-63. PubMed Abstract | Publisher Full Text | Free Full Text | Faculty Opinions Recommendation

130. Wang $Y$, Godec J, Ben-Aissa K, et al:: The transcription factors T-bet and Runx are required for the ontogeny of pathogenic interferon- $\gamma$-producing $\mathrm{T}$ helper 17 cells. Immunity. 2014; 40(3): 355-66.

PubMed Abstract | Publisher Full Text | Free Full Text

131. Morrison PJ, Bending D, Fouser LA, et al:: Th17-cell plasticity in Helicobacter hepaticus-induced intestinal inflammation. Mucosal Immunol. 2013; 6(6): 1143-56.

PubMed Abstract | Publisher Full Text

132. Ahlfors $\mathrm{H}$, Morrison $\mathrm{PJ}$, Duarte $\mathrm{JH}$, et al.: IL-22 fate reporter reveals origin and control of IL-22 production in homeostasis and infection. J Immunol. 2014; 193(9): 4602-13. PubMed Abstract | Publisher Full Text | Free Full Text

133. Harbour SN, Maynard CL, Zindl CL, et al:: Th17 cells give rise to Th1 cells that are required for the pathogenesis of colitis. Proc Natl Acad Sci U S A. 2015, 112(22): 7061-6.

PubMed Abstract | Publisher Full Text | Free Full Text | Faculty Opinions Recommendation

134. Dain R, Chen $\mathrm{Y}$, Kanno $\mathrm{Y}$, et al:: Interleukin-23-Induced Transcription Factor Blimp-1 Promotes Pathogenicity of T Helper 17 Cells. Immunity. 2016; 44(1) 131-42.

PubMed Abstract | Publisher Full Text | Faculty Opinions Recommendation

135. A Wang YH, Voo KS, Liu B, et al:: A novel subset of CD4(+) T(H)2 memory/ effector cells that produce inflammatory IL-17 cytokine and promote the exacerbation of chronic allergic asthma. J Exp Med. 2010; 207(11): 2479-91. PubMed Abstract | Publisher Full Text | Free Full Text | Faculty Opinions Recommendation

136. Irvin C, Zafar I, Good J, et al:: Increased frequency of dual-positive TH2/TH17 cells in bronchoalveolar lavage fluid characterizes a population of patients with severe asthma. J Allergy Clin Immunol. 2014; 134(5): 1175-1186.e7. PubMed Abstract | Publisher Full Text | Free Full Text

137. Tortola L, Jacobs A, Pohlmeier L, et al.: High-Dimensional T Helper Cell Profiling Reveals a Broad Diversity of Stably Committed Effector States and Uncovers Interlineage Relationships. Immunity. 2020; 53(3): 597-613.e6. PubMed Abstract | Publisher Full Text | Faculty Opinions Recommendation

138. Tibbitt CA, Stark JM, Martens L, et al.: Single-Cell RNA Sequencing of the T Helper Cell Response to House Dust Mites Defines a Distinct Gene Expression Signature in Airway Th2 Cells. Immunity. 2019; 51(1): 169-184.e5. PubMed Abstract | Publisher Full Text | Faculty Opinions Recommendation 